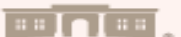

J. Garcfia López casas funerarias

\section{[E Bodiogón

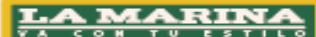

Kidzanig.

(9.) Tornel

Gupo

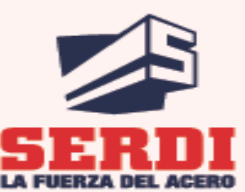

URRER.
Lapi:

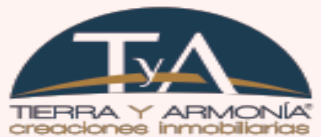

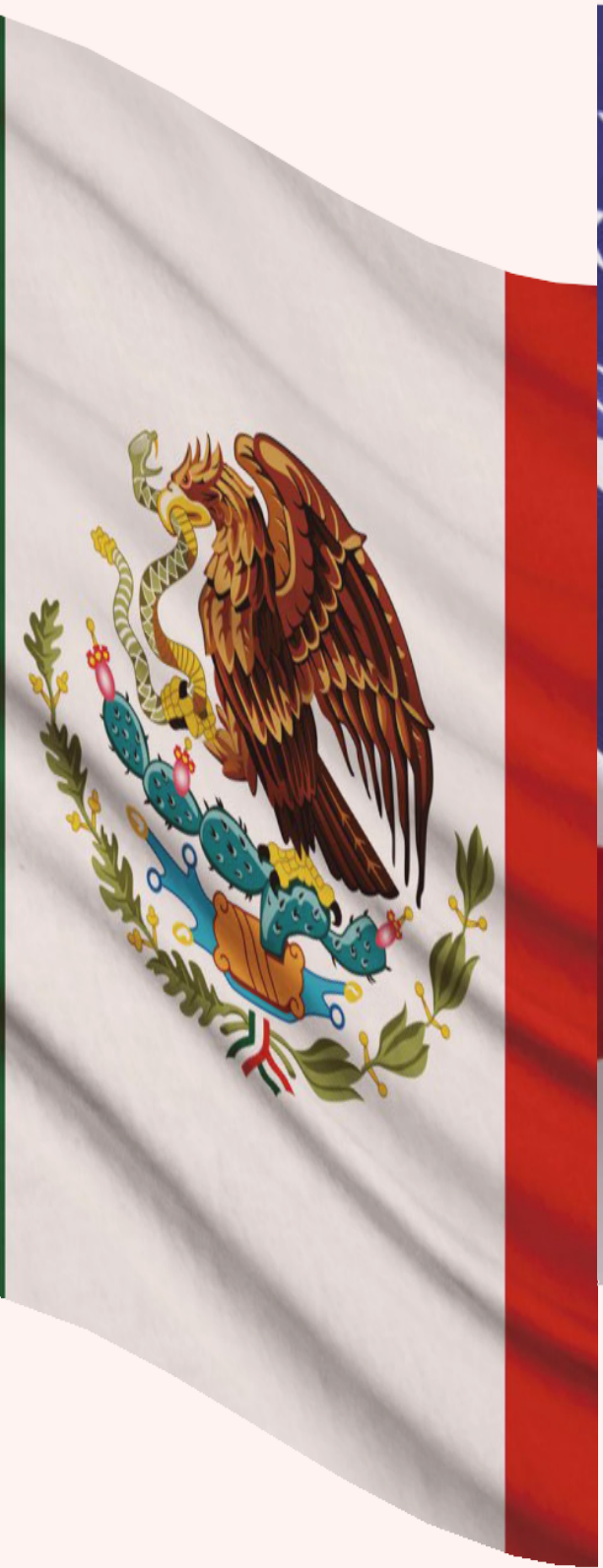
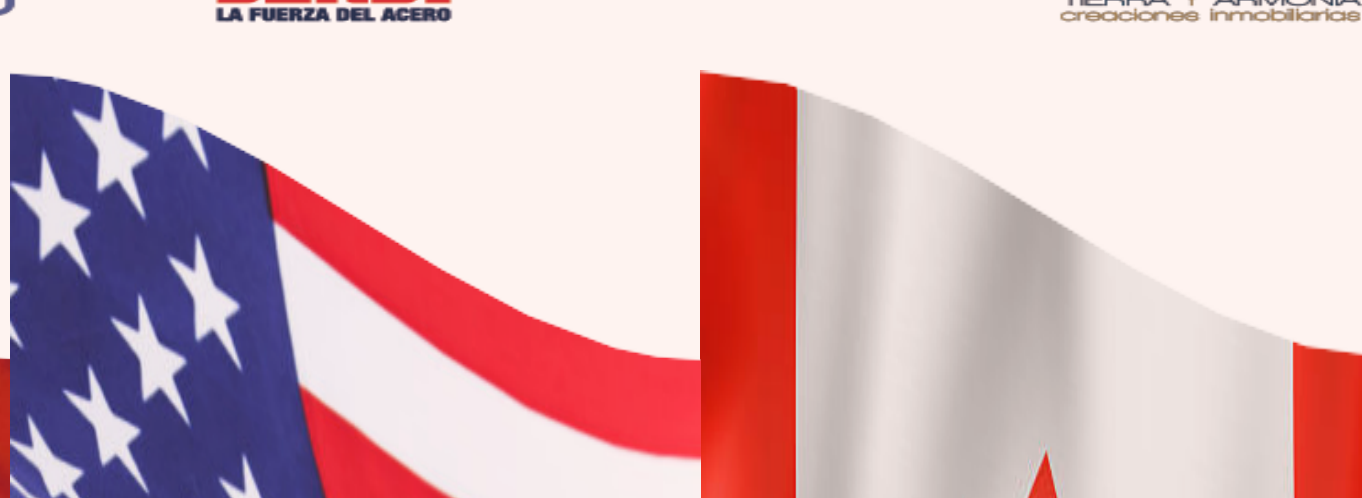

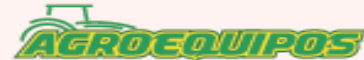

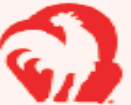

Agroindustrias del Norte cerangir?

andamios atlas


manufacturas metáncas

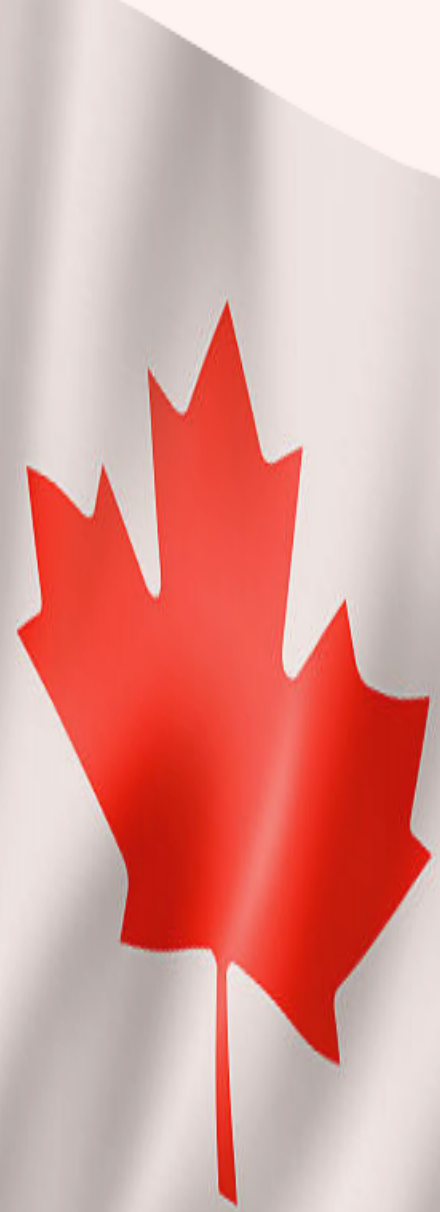

experiencias
xcaref 


\title{
Scenarios for small and medium enterprises provisions in USMCA renegotiation. A critical analysis of challenges and opportunities
}

Escenarios para las disposiciones de pequeñas y medianas empresas en la renegociación del T-MEC. Un análisis crítico de los desafíos y oportunidades

\author{
José G. Vargas Hernández \\ Visiting Scholar at Laurentian University \\ University Center for Economic and Managerial Sciences of the Universidad de Guadalajara (Mexico) \\ Corresponding author: josevargas@cucea.udg.mx \\ Jorge Armando López Lemus \\ Universidad de Guanajuato (Mexico)
}

(Recibido: 28/08/2018. Aceptado para publicación: 04/07/2019)

DOI: 10.22201/fe.24484962e.2018.v7n13.a3

\section{ABSTRACT}

The objective of this document is to establish some scenarios for small and medium enterprises (sMEs) based on a critical analysis of the provisions in the renegotiation of the United States-Mexico-Canada Agreement (USMCA), its challenges and opportunities. The critical analysis starts from the questionable position of USMCA's withdrawal and its consequences for SMES of not giving continuity through a renegotiation process between the three partners. Based on some sources of information, the study of the results of the North American Free Trade Agreement (NAFTA) and the USMCA, and the strategic review of their challenges and opportunities for SMEs, some possible scenarios are established after the renegotiation of the USMCA, as well as some strategic proposals for SMEs. Key words: Challenge, USMCA, opportunity, renegotiation, scenario, SMEs.

Clasificación JEL: F13, F15, F20, F41, F43, F51, F53, F61, F62, N82, N86.

\section{RESUMEN}

El objetivo de este documento es establecer algunos escenarios para las pequeñas y medianas empresas (румеs) a partir de un análisis crítico de las disposiciones en la renegociación del Tratado entre México, Estados Unidos y Canadá (T-MEC), así como de sus desafíos y oportunidades. El análisis comienza desde la posición cuestionable de la retirada de T-MEC y sus consecuencias para las pymes de no dar continuidad a través de un proceso de renegociación entre los tres socios. A partir de algunas fuentes de información, del estudio de los resultados del Tratado de Libre Comercio de América del Norte (TLCAN) y el T-MEC, y de la revisión estratégica de sus desafíos y oportunidades para las PyMEs, se establecen algunos escenarios posibles tras la renegociación del T-MEC, así como algunas propuestas estratégicas para las PyMEs.

Palabras clave: cambio, T-MEC, oportunidad, renegociación, escenario, PyMEs.

JEL Classification: F13, F15, F20, F41, F43, F51, F53, F61, F62, N82, N86. 


\section{INTRODUCTION}

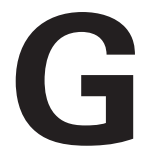
lobal economy has changed significantly in the last three decades especially due to technology advances with the widespread use of Internet for e-commerce and trade, affecting consumer habits, communication and managerial practices, supply chain management, etcetera. While the notion that trade is an engine of economic growth (Kravis, 1970; Lewis, 1980) benefiting all the involved participants, an assumption that cannot easily be refuted theoretically, however, free international trade has never been implemented.

On September 30, 2018, the United States, Mexico and Canada generated an agreement to modify the North American Free Trade Agreement (NAFTA), so on November 30 at the summit of Buenos Aires, Donald Trump, Justin Trudeau and Enrique Peña Nieto signed the United States-Mexico-Canada Agreement (UsmCA) (García Grande and Echevarría Lasaga, 2019) agreement under an economic logic of According to the conclusions of the theory of international free trade, which states that it allows each country to specialize based on a comparative advantage. Free trade through specialization benefits all countries involved promoting economic efficiency and growth (Kondonassis and Malliarls, 1996).

Despite the serious and broader concerns of disparities in income and cultural and ethnic differences that could pose serious obstacles for economic and market integration among the three partners of USMCA, 24 years of implementation and operation, the results confirm that the agreement has benefitted all the three partners. It also has confirmed that the two neighbors of United States, Canada and Mexico are of considerable foreign-policy importance (Krueger, 1992), which is to say that the political dimension is linked to economic decisions in USMCA.

The renegotiations of USMCA is a unique opportunity for economic analysts, to investigate, analyze and contrast the new and then old issues that have motivated the North American economic and market integration. Proponents and critics of the renegotiation of USMCA agree on modernization and reevaluation of the agreement considering the challenges and opportunities, although they have contrasting views on the process of revision.

This paper addresses the main concerns on USMCA provisions renegotiation and its impact on the small and medium enterprises (SMEs onwards) making a critical analysis on recent developments in strategic terms of challenges and opportunities. Finally, this paper develops some scenarios and make some proposals.

\section{USMCA RENEGOTIATIONS}

NAFTA entered into force on January 1, 1994, as the first of a new generation and most comprehensive free trade agreement negotiated at the time (Villarreal and Fergusson, 2019). The NAFTA was instrumental in developing closer trade and investment relations among the three countries: United States (U.S.), Canada and Mexico. Through NAFTA, the United States and Canada could have more access to the Mexican market after the removal of tariffs and quotas and U.S. market was opened to increased imports from Canada and Mexico. Tariffs phased out for sensitive products such as sugar and corn, after 15 years when the agreement went into effect to become duty free.

NAFTA removed investment barriers, protected investors and provided mechanisms for the settlement of disputes. Hufbauer 
and Schott (1992) suggested that Mexico anticipated that agreement would reduce the threat of U.S. protectionism, would reinforce trade reforms and would provide Mexican small and medium enterprises with more opportunities for export to the United States. As a consequence, Mexico would rise the employment and income which could further increase the gains of Canadian and U.S. small and medium sized business. For example, NAFTA integrated the motor vehicle industry by removing protectionist policies. Also included liberalization commitments and specific exceptions to national treatment.

The agreement lock in trade and investment liberalization among the three countries. Since NAFTA, the three partners have relationships of cooperation on issues of mutual interest, expanding economic linkages and forming integrated production, distribution, logistics and marketing chains, improving working conditions and living standards of employees and consumers Villarreal and Fergusson (2019).

NAFTA market has become the largest destination for small and medium enterprises of partners. Mexico and Canada were the largest destinations of U.S. small and medium-sized enterprises with more than $95 \%$ of their exports in 2014. Some economic analysts contend that Mexican economic reforms added resilience to its economy that will bring greater economic growth. The recent finance and fiscal reforms in Mexico creates more competition in the banking sector increasing the access to finance and credit for small and medium sized business.

The agreement represented the first opportunity for establishing labor and environmental provisions in a new type of relationships of cooperation among the NAFTA partners. However, some critics blame NAFTA for a decline in labor conditions, employment and wages in United States and for lack of improvement on labor and environmental standards (Hufbauer, Cimino, and Moran, 2014; U.S. Chamber of Commerce, 2015).

The NAFTA initiated in 1994 linking the Canadian, Mexican and United States economies creating a market with 490 million consumers. The renegotiation talks began in August 2017. The economic model emerged out from NAFTA arrangements faces new challenges. The interdependence on trade among the three partners of NAFTA is challenged by a high percentage of U.S. content on Canadian and Mexican exports.

United States has officially proposed for updating the trade agreement with its summary of objectives for the NAFTA renegotiation centered on modernization to address a fairer deal expanding rules of origin to include more U.S. content and to balance trade reducing bilateral trade deficits with Canada and Mexico. NAFTA renegotiation and modernization has been a priority for the U.S. Government and now it is also for Mexico.

The reason behind the U.S. renegotiation is because NAFTA is characterized by the President as the "worst trade deal," that has resulted on a trade deficit with Mexico and Canada and has stated several times the potential withdrawal from the agreement. NAFTA renegotiation is a constructive alternative to strengthen economies. However, it is very debatable the use of trade agreement provisions to overcome the trade deficit because macroeconomic fundamentals determine trade imbalances (Bergsten, 2017). Renegotiation of NAFTA is more likely to affect the composition of trade partners but it is very questionable its impact on the trade deficit. If in the renegotiation of NAFTA there are not clear provisions it is not clear how is possible to reduce trade deficit. 
The United States is looking at the renegotiations of a new USMCA treaty derived from NAFTA to improve trilateral cooperation in the security and energy sectors that have greater open access to investment and trade in the oil sector. On the part of Mexico, one can try to improve the energy sector, mainly the state oil company Petróleos Mexicanos (Pemex), to compete in the market.

The renegotiation of USMCA includes the issues of dispute resolution system, rules of origin, salary requirement, Tariffs on cars, taxes, agriculture, minimis level, safeguards, trade remedies, environment, intellectual property and data, digital commerce, financial services (García and Echavarría, 2019). USMCA has significantly benefited motorized vehicles, auto parts, agricultural industries and small and medium enterprises.

Dispute resolution system. The United States seeks to discourage the investment of North American smes that have a participation in the market of third parties, specifically those that are operating in Mexico for what the United States raised through USMCA to eliminate completely the system of resolution of investment-State disputes. Likewise, it was possible to have a sectorized request in which it allows U.S. companies to have contracts for the generation of energy, telecommunications, infrastructures such as gas and oil with the Government of Mexico.

Rules of origin. For a good to be free of tariffs, it should have some regional value. The United States raised the minimum increase from $50 \%$ to $75 \%$. The initial requirement will be $66 \%$ and from January 1, 2020, from the date will increase three points each year until reaching 75\% before January 1, 2023.

Salary requirement. The UsMCA treaty establishes that between $40 \%$ and $45 \%$ of the value of the vehicle manufactured in Mexico must be produced by workers who have a salary of $\$ 16$ per hour, while for the United States and Canada will increase to $\$ 29$ per hour by the year 2023. The main affected in this rule will be Mexico, because workers earn an average of $\$ 8$ per hour. That is why the United States government through USMCA seeks that automobile manufacturers do not invest in Mexico, but if in the United States.

Tariffs on cars. In the event that the United States imposes tariffs on the importation of automobiles under section 232, Mexico and Canada will have annual exemptions of 2.6 million vehicles for each of the countries. Also, if there are tariffs, 10,000 million dollars in parts of vehicles from Mexico and 32,400 million dollars in parts of Canada will be exempt.

Taxes. Exports with a regional content of at least $75 \%$ will be subject to a coupon of 2.6 million units of light vehicles exported from the United States, Mexico and Canada. Exceeding the quota established in the USMCA market, the merchandise will be subject to a tariff of $2.5 \%$ only if they comply with the established rules of origin.

Farming. UsmCA provides the United States with $3.6 \%$ access to the dairy and agricultural market. Likewise, USMCA favors the United States in that both Mexico and Canada gradually open up the market to the importation of North American products. promoting the elimination of support granted by the governments of Mexico and Canada to their producers.

Minimis level. It is the maximum value that an asset can enter without paying taxes or tariffs. Mexico will increase its de minimis level from 50 to 117 dollars in customs duties and 50 dollars for taxes. in the case of Canada, it will increase to 117 dollars in customs duties and 31 dollars for taxes.

Safeguards. UsmCA will allow the United States to refrain from imposing tariffs 
under section 232 on Mexico and Canada during the seventy days following its general imposition. Within the established period, the United States will maintain negotiations in order to achieve an appropriate solution in trends in the commercial sector. USMCA will allow both Mexico and Canada to respond with similar reprisals to the United States under section 232 is inconsistent of the country subscribed to the USMCA.

Trade remedies. UsMCA promotes cooperation to share information by which USMCA member countries must exchange customs information on both imports and exports in transit with the aim of combating anti-dumping and anti-dumping measures and safeguard measures.

Environment. In the USMCA agreement, the United States undertook to include seven multilateral agreements. However, many environmentalists have criticized the non-enforceable language of the USMCA because of the seven agreements referenced, only one has standard language, two of them do not contain binding language, while four of them are not mentioned.

Intellectual property and data. The UsMCA agreement establishes a ten-year data protection for biological medicines, as well as an application of the eligible products to qualify for this protection. Regarding the copyright and the determination of responsibilities of Internet service providers (ISP onwards), USMCA establishes a system based on notification and withdrawal, which is based on the North American model. That is, once the content is infringing is notified to the ISP, and this should remove the content and ensure it does not reappear on the platform.

Digital commerce. UsMCA increases the threshold of minimis to online commerce so that it can be tax-free. Likewise, tariffs on digital products that are acquired electroni- cally will be prohibited. On the other hand, cross-border data will be guaranteed and the limits to the location and processing of the data will be reduced. Finally, USMCA excludes the disclosure of source codes, as well as algorithms with the purpose of protecting the competitiveness of digital providers.

Financial services. USMCA establishes new measures in order to free the financial sector. Therefore, access to the national market is established with the prohibition of quantitative restrictions that may limit American financial companies. Likewise, the same national treatment is guaranteed to North American financial services companies as to local ones.

Only a few small and medium-sized companies follow the key issues and possible outcomes of the negotiation process through the USMCA treaty.

\section{BACKGROUND OF THE SMES}

Small and medium business are living in an era of tremendous global development and change which requires decision making and policy implementation confronted by challenges and opportunities to shape their own developments and serve their best interests. The industrial sectors of auto mobiles, motor vehicles and parts, agriculture and small and medium enterprises have been significantly received benefits from the creation of NAFTA. Exports from United States to Mexico have grown in motor vehicles and parts $262 \%$. Agricultural exports to Canada and Mexico have increased $350 \%$.

Mexico and Canada are the largest market destinations for U.S. small and medium-sized enterprise's (Dubbert and Sengenberger, 2018). USMCA generates multi-million dollar industries in the sMEs in most of the American states because of its business facilities 
and commercial advantages. In its 24 years of operation, 33 states have sold more goods and services to Canada and Mexico than to the rest of the United States. In 2016, the last exercise prior to the declaration of the commercial war, exports to Canada ranged from 9,000 million dollars from Washington State to 23,700 million dollars from Michigan. While the sales to Mexico went from the 2,000 million of Hawaii to the 91,700 million of Texas.

Fiscal reforms in Mexico incentivize participation of sMEs in the formal, tax-paying economy by offering credit, home loans, insurance, retirements. Among the sMEs, USMCA seeks to boost formal-sector productivity and employment. Small-and medium-sized enterprises employ over $60 \%$ of Mexican workers including informal sector. Millions of jobs created by smes depend on USMCA trade, which remains critical to workers, owners and companies to generate new opportunities. However, productivity in Mexican small businesses fell by $6.5 \%$ per year between 1999 and 2009 while during the same period, large companies increased by $5.8 \%$ per year (Bolio, et al., 2014).

Majority of SMEs participate and use USMCA to save costs, in cross-border transactions although sometimes they remain dangerously passive as to its outcome. Since NAFTA went into effect, Mexico and Canada have evolved into the largest two export destinations for U.S. small and medium businesses (U.S. Chamber of Commerce, 2017). Across Canada there are 109,000 small and medium-sized member businesses (Canadian Federation of Independent Business, 2018) out of which one in five are involved in foreign trade.

The issue of growing and strengthening SMEs that accounts for $90 \%$ of worldwide business, is an important business case (Gasiorowski-Denis, 2015). sMEs constitute over
$90 \%$ of exporters of goods and services in the three countries members of USMCA. Currently, SMEs two-thirds import and one-third export either products or services (Canadian Federation of Independent Businesses, 2018).

The resource-based theory and the capability theory of firms sustain that the internationalization process of SMEs requires resources and capabilities (Martineau and Pastoriza, 2016). Also the institutional theory suggests that institutions and public policy play an important role in strategic decision making about locating, scaling and linking SMEs to value added chains of investment, design, production, logistics, marketing and international trade. Also institutions and public policy supporting investments, credit, certification process, etcetera, are relevant for the internationalization processes of SMEs.

Competitive economics is critical for SMEs to cross-border trade and international trade procedures to achieve cost-effective solutions through the access to technology delivering speed, ease and security such as the block change technology. Borders among the three countries have thickened due to the enforced security measures damaging the trade relationships. This situation gives an opportunity to find initiatives and procedures based on reciprocal collaboration to facilitate cross-border trading.

SMEs engaging in international markets make major contributions to the economy by being more productive (Baldwin and $\mathrm{Gu}$, 2003) become more likely to export (Melitz, 2003; Baldwin and $\mathrm{Gu}, 2003$ ) and having higher revenues, paying higher wages (Mayer and Ottaviano, 2008), investing more on research, innovation and development having higher rates of technology adoption (Lileeva and Trefler, 2010).

Innovation of SMEs boosts production, employment and more competition to benefit 
consumers. Innovation in sMEs can come after better access to credit and other financial instruments that enable international and cross-border trade. SMEs can innovate and develop the capacity to conduct cross-border transactions of goods and services through the use of Internet, digital devices, reducing cost and space of firm size required. SMEs are heavy web and Internet users to trade and to source products and services internationally. Besides, sMEs with high web use realize higher percentage of sales growth on average and low web users had no presence or sales decline.

Martineau and Pastoriza (2016) suggest that education, experience and growth orientation personality of the sMEs owners are relevant factors in decision making to export. SMEs owners with higher level of education and management experience are more positively correlated with export propensity because they are enabled to likely become exporter of products and services.

SMEs under the framework of the USMCA have to keep searching for new markets. SMEs are efficient exporters contributing significantly to the economy of USMCA members. Small and medium-size enterprises among the USMCA countries make up a growing percentage in the share of international trade. The state's members of USMCA are committed to provide support and stimulate to establish mechanisms for SME to meet requirements for trade liberalization, encouraging greater participation by sMEs in regional supply chains aimed to export orientation. The agreement includes a Trilateral Dialogue to increase the efforts for access of sME to the North American Free Trade market.

Given the importance of the North American free market, many sMEs are concerned about the renegotiation process of USMCA. Protecting the free trade fundamentals in the negotiations of USMCA is a relevant matter to have settled the sMes. Matters on SMEs subject to negotiations are the markets, strategic information sharing and cooperative activities with other local, domestic and international business.

The renegotiation of the new USMCA normal has positive and negative impacts on SMEs, generally determined by geography and industry. Large companies from the e-commerce sector have supported sMEs to marketing, distribute and sell products to foreign markets, for example "e-Bay enabled sMEs," were exporters in Mexico, Canada, and in the United States. Regarding e-commerce, Mexico faces substantial challenges regarding public distrust on digital and online systems, low Internet connectivity, etcetera. Despite this problem, the e-commerce market has grown (Export.gov, 2017).

SMEs need to adapt quickly the new trade arrangements to the new USMCA normal in order to avoid potential harm manufacturing and services while benefitting others.

\section{CHALLENGES OF SMEs}

A report of the Organisation for Economic Co-operation and Development (OECD, 2017) stated that " (...) a key challenge for many sMEs is to identify and connect to appropriate knowledge partners and networks". The success for the sMEs depends of their "their access to strategic resources (...) such as education and training, innovation and infrastructure."

The USMCA is a challenge for sMEs to gain preferred access to more than 500 million consumers. NAFTA partners are the largest destinations for small-business exports between each other. For example, U.S. small and medium-sized business represented more than $95 \%$ of all its exports equiva- 
lent to $25 \%$ of total value into the Canada and Mexico markets. 95\% of U.S. small and medium enterprises are small and medium companies' exports into the other members of USMCA, Canada and Mexico. The largest export destinations of U.S. small and medium-size enterprises are Canada and Mexico representing more than $95 \%$ in 2014 and becoming the largest markets for United States (International Trade Administration, 2016).

Canadian small and medium sized firms that already trade with the other USMCA parties, United States and Mexico, are not very or somewhat familiar with the agreement (Kelly, 2018). However, exports from Canada and Mexico to United States have risen substantially since NAFTA. Similarly, cross-border investment has increased significantly as well. Over the past three years, the Canadian

Canadian and Mexican SMEs are facing the uncertainties of the USMCA renegotiation with the possibility of the trade deal collapse.

SMEs face several challenges to position themselves getting support to achieve resources and capabilities aimed to create, develop and reinforce the links within the international value chain. Free trade among the three countries has been complex and diverse because final product could have combinations of value added from all trading partners. Trade tariffs and trade barriers disrupt production chains of SMEs, which increase costs for consumers, reduce efficiency and competitiveness in production and thousands of lost Jobs.

An important challenge is the reduction of low value shipments requiring minimal custom paperwork and costs by supporting the digital marketplace and promoting inclusivity for SMEs. Engaged sMEs leverage digital platforms to access the different markets. The existent integration in North
America translates into high opportunity costs derived from inconsistent and incompatible regulations.

The eco-system for sMes shares policy information among the different regions to access to the best practices of financial processes connected through a web portal that allows encode invoices. SMEs optimize some internal processes of export initiatives through digitalization such as payments, invoices, settlements and reconciliations to improve speed, security and ease of trade transactions. However, Hufbauer and Wong (2011) found that savings to customs, express shipping, sMEs and consumers from raising the threshold outweighed lost government revenue.

The majority of female owned smes (51.9) and non-female SMEs owned (9.3) of all SMEs (49.7) grew between $1 \%$ and $10 \%$ of an average annual revenue between 2012 and 2014. The export propensity of Canadian small-sized sMEs in 2014 was $20.7 \%$ meaning the share of all SMEs that export Canadian female-owned smes follow the same trends as all sMEs but outshine female owned non-exporters in larger size located in export intensive industries, education and experience, more likely to be born outside Canada (Office of the Chief Economist, 2016).

The propensity of micro-sized sMEs, between 1 and 4 employees, was $53.0 \%$, tiny SMEs between 5 and 19 employees were $34 \%$, small SMEs between 20 and 99 employees $11.1 \%$ and medium-sized sMEs between 100 and 499 employees were $1.6 \%$. The industries of manufacturing, wholesale trade and professional and technical services, have the highest export propensities of enterprises for exporting. In Canada, Ontario is the location where SMEs have greater propensity to export likely tied to industry (Office of the Chief Economist, 2016). 
There is also an increasing participation of female owned exporting sMEs, as it has been reported by the Office of the Chief Economist (2016). According to this report, sMEs female owned represented only $15.7 \%$ and only $11.1 \%$ of all exporting smes. The data used is from the Survey on Financing and Growth of Small and Medium Enterprises with over 97 thousand female smes. This report examines characteristics and differences between majority female owned SMEs exporters and non-exporters.

Canadian smes exporters are larger and have more control and ownership over relevant resources and capabilities than the other SMEs non-exporters (Orser et al., 2010). Investors and owners of sMEs challenge regulations using broad language and designed to further policies related to issues of environment, labor, safety, health, etcetera (Hufbauer and Schott, 2005).

Female's owners of businesses tend to be smaller more oriented towards local markets and less likely to participate in international markets. Female owners of exporting sMEs in Canada are larger in terms of number, more educated and experienced that non-exporting SMEs owned by non-females. Female SME exporters are more traditionally export intensive industries, although they are smaller and are less likely to participate in less export-intensive than non-females (Office of the Chief Economist, 2016). Female sME owners face perceived and real obstacles to growth (Orser, 2007) although may be less interested in growth as a revenue (Poggesi, Mari, and De Vita, 2016).

\section{RENEGOTIATION CHALLENGES OF USMCA}

The SMEs are an issue for USMCA renegotiation that could be modernized using as a reference other more recent agreements such as the Trans-Pacific Partnership (TPP), considering recent technological and scientific developments, managerial and regulatory practices. Regulatory challenges brought SMEs under the investor-state dispute resolution provisions of USMCA have to be overcome as a source of controversies.

SMEs are being discouraged for growing and expanding businesses by the rising tensions in USMCA renegotiations and the imposition of marginal trade tariffs. Also, related industry is already suffering with the trade tariff already imposed to steel and aluminum by United States, such as the documented case of the firm in the boating industry (Condon, 2018). Local business could suffer with the withdrawal as the case of Boating Ontario representing several sMEs across the province with more than 30,000 direct and indirect jobs is projecting a 20 per cent job reduction in 2019 (CBC News, 2018).

Any disruption to the economic relationships of USMCA, could have economic adverse effects for the three partners on productivity, competitiveness, employment, investments, etcetera. Low skilled employment would decline by 125,000 for Canada and 951,000, for Mexico respectively (Walmsley and Minor, 2017). Any change to UsmCA has a broad and varied impact on Canadian, Mexican and even United States small and medium businesses. If United States decides, as it has been threatening, to pull out of USMCA, trade with Canada will revert to the 1988 signed Canada-United States Trade Agreement (Galarneau, 2017). The case of Mexico is different not having a previous United States-Mexico trade agreement and the impact on Mexican small and medium enterprises will be devastating.

However, there is no coincidence of interests between Mexico and Canada because 
they are competitors both economically and politically. From the economic point of view, they have strong struggles for foreign and commercial investment. That is why Mexico and Canada sell to multinational companies as one of the best options to serve the American market. On the other hand, they compete from the political point of view due to the attention of the U.S. government regarding bilateral issues (Condon, 2018).

Today the three economies are economically interdependent in such a way that any decoupling would be an economic catastrophe and risking the cooperation and shared intelligence to deal with strategic challenges. Among these strategic challenges are migration and regional security, free movement of goods and services, coordinated response to natural disasters and pandemics, etcetera (Anderson, 2017).

The United States is renegotiating NAFTA through the USMCA agreement with the objective of imposing tariffs on products imported from Canada and Mexico, which leads small and medium-sized business owners to face a triple blow that could eliminate the value of their business. and the work of his life. The Canadian province, Ontario and the cities of Monterrey in the state of Nuevo León or Naucalpan in the state of Mexico have a small and medium manufacturing company that depends largely on exports to the United States to survive. This situation can lead small and medium businesses to be sold by owners who have worked very hard in their lives and are forced to have only the sale of their business to have health finances.

Canada's trade commissioners, and Mexican government are concern about the imposed trade tariffs by U.S. government and committed to including small business in the USMCA trade agenda. Small and medium businesses are supported by governments of
Canada and Mexico to renew USMCA on new grounds in international trade of goods and services despite the threats of United States imposed trade tariffs, which are damaging the U.S. small and medium enterprises.

SMEs business hiring is slowing cutting back jobs of companies, hurting workers by the escalating trade disputes. Employment and investments of car dealers in Canada and Mexico could be at risk if automobiles and auto parts tariffs come to pass imposed for imports to United States and the new USMCA deal is not secured.

Importers and exporters SMES on USMCA are under attack of aggressive trade policies such as the tariffs. United States have hit back the other members of USMCA, Mexico and Canada, for retaliating against tariffs with the World Trade Organization (WTO) complaint. The main challenge facing SMEs on USMCA renegotiation is to reach an agreement with clear and stable regulations supporting the free fair trade and investments flows in North America, providing certainty to all the economic agents involved. Under the assumption that free trade must be a fair trade, Canadian small and medium firms have urged their government to stand against any increase on trade tariffs and at the end charging the duties and sales taxes to the consumers. Tax regimes and other legislations of each country member of USMCA affect the SMEs and have an impact on final consumers. Tariffs are driving up the costs of imports needed by companies, including the SMEs.

Small and medium businesses have a passive approach to the USMCA renegotiations considered to be a sense of fatalism. Most of the smes casually follow or are not following the USMCA discussions and only few small and medium-sized business have contingency plans in the event of United 
States withdrawal from USMCA. If the threat of United States to withdraw from USMCA is achieved, there will be legal challenges from small, medium and large business to claim compensation for damage, members of congress may take legislative action or blocking funding to carry out the withdrawal.

The existing substantial research demonstrates that smaller and medium companies are likely to be hardest hit by the uncertainty of USMCA withdrawal because they respond to policy uncertainties by reducing investments, jobs and risks (European Commission, 2016), which tend to be harder to absorb when having few customers to spread risk among them. The cost of United States withdrawal from USMCA would increase the cost to more than $\$ 50$ billion U.S. dollars.

A little more than half of and medium-size businesses are aware that the discussions will lead to a successful renegotiation of USMCA or with little effects. Less than half of SMEs are aware that the withdrawal from USMCA would have negative effects in industry and the other half is aware of a negative effect on individual businesses. Canadian small and medium-sized businesses are aware of the need to back up a plan to face the tariff disputes.

The outcomes of USMCA renegotiations will have direction on policy implications for the broader relationship of economic cooperation on investment, trade, labor, environment, etcetera, among the parties. The renegotiated USMCA partners have an opportunity to develop policy guidelines and constraints to SMEs on trade interventions to prevent and preclude new trade frictions in the future. The new generations require that USMCA renegotiation expand upon further liberalizing trade and investment, creating new markets of goods and services to provide further benefits in terms of job creation, better wages, major quality and lower prices of goods and services, economic efficiency, etcetera.

Some of the relevant challenges that USMCA renegotiation have they should include stronger and more enforceable labor regulations and protections, provisions on potential currency manipulation, and stricter rules of regional origin. The complexity of the rules of origin application add to the traditional trade cots some additional administrative costs for small and medium enterprises which lead not to be benefited of USMCA tariff preferences and take advantage of the most favored nation tariffs to import products and services. USMCA's rules of origin are toughest and burdensome for SMEs as an estimated $7 \%$ in compliance costs. Tightening rules of origin add costs to trade that in turn could be costly to consumers and may introduce inefficiencies for businesses (Freund, 2017).

More than half of small and medium-sized businesses will pass down the costs of tariffs to consumers or absorb costs and reducing investments, which lead to reduce competitiveness. USMCA renegotiations has the potential to affect an impact on developments made on issues of common interest between the three countries for the last two decades in cooperation in areas of security, energy and competitiveness, migration, etcetera.

Concerns over USMCA labor and environmental provisions challenge the renegotiation of USMCA. Environmental regulations and programs could be challenged under a framework of the trade agreement and not under national trade laws to guarantee a legitimate nondiscriminatory implementation. Environmental regulations, standards, issues and concerns are usually challenged under dispute resolution mechanisms (Gaines, 2007; Sinclair 2015). Sustainable develop- 
ment should be a core commitment in any new framework of renegotiated USMCA. Renegotiation of NAFTA's implies the inclusion of regulations related to environmental concerns to manage the environmental challenges (Torres, 2002; Carpentier, 2006).

For example, Canada had faced 35 challenges on environmental regulations concerning pollution control, resource management, toxic waste disposal, mining, lumbering, etcetera (Sinclair, 2015). An ongoing action is the challenge brought by an oil and gas company against a Quebec's fracking ban (ICSID, 2017). The United States has been challenged by 20 claims including six challenges to environmental regulations and resource management and have not paid out compensation (Aguilar Alvarez and Park, 2003). Mexico has faced 22 challenges of which only 4 cases involved environmental issues. The most critical has been the case of Metalclad as an abuse of the investor-state dispute settlement structure. This case confirms that the dispute mechanisms systematically favors investor interests to the detriment of the environment and the public.

It seems that the proposals on trade policymaking in USMCA renegotiation encompasses environmental and social concerns and issues including income distribution, public health, labor rights, worker dislocation and poverty alleviation, etcetera. As a priority on the USMCA negotiation, labor and environmental standards should be updated, improved and enforceable to comply, for example with the Trade Promotion Authority (TPA) objectives for labor.

\section{OPPORTUNITIES}

The UsmCA renegotiation offer a unique opportunity for economic analysts to investi- gate, analyze and contrast the issues related to SMEs that have motivated the economic integration process in North America. SMES have a large stake in USMCA renegotiation because they have a very significant market of products and services. A renegotiation of USMCA is a new opportunity for SMEs to assess cross-border market conditions and opportunities for improve trade related to labor and environmental collaboration.

The renegotiation of USMCA could provide an opportunity to modernize certain related issues to SMEs exports and imports. Small and medium-size enterprises is an issue for USMCA renegotiation that could be modernized using as a reference other more recent agreements such as the TPP, considering recent technological and scientific developments, managerial and regulatory practices. Modernization of USMCA building on shared interests, commercial and security ties requires to SMEs to update technological developments and agree on new rules of governing digital flows, financial services, e-commerce, export of digital goods and services, energy, etcetera, to take full advantage of new opportunities. For that, it is also required protection of intellectual property on digital contents.

The renegotiation of UsMCA offers the opportunity to governments of the three countries of North America to create fair trade for SMEs and protect their local interests in accordance to the business communities in order to build relationships of cooperation and harness the benefits of the agreement. Also, USMCA renegotiated could contribute to create new opportunities for investment and trade for small and medium-size enterprises in North America, having a positive effect on employment.

The renegotiation of USMCA has the opportunity to make it more progressive by 
strengthening among other provisions, the ones related to SMEs, labor and environment. International trade when expanding the export markets must benefit the three countries members of USMCA, ensuring that exports and imports of products and services for small and medium sized companies can be done easily, with cost efficiency, thus benefitting consumers and sMEs.

The opportunity cost of low-level achievements and commitments in USMCA is higher due to the existing deep integration among the three national economies and markets. A set of negotiating objectives to update USMCA provisions could prioritize fair free trade of goods and services of sMEs, inclusive and responsible by incorporating mechanisms of cooperation related to labor en environment standards, energy security, transparency and anticorruption, etcetera.

Among the USMCA negotiating objectives should be included provisions on government anticorruption (Corchado, 2017). Also, trade relations should not remain separated from security cooperation in the relationship (Wilson, 2017).

The governments of Canada, the United States and Mexico agree on the inclusion of a small and medium sized business chapter in the renewed agreement, even amid the uncertainties of the renegotiation process of USMCA. However, the awareness of the renegotiations of USMCA remains low, but interest in partnering with small and medium companies among the parties as an opportunity to develop in international markets is high. The Canadian and Mexican governments have committed to modernizing USMCA by staying at the negotiating table, although the renegotiation is unclear.

The modernization of USMCA requires to update the new labor, digital and environmental developments strengthening data privacy and intellectual property rights. Renegotiation of USMCA offers an opportunity to address the issues of efficient environmental regulations and sMEs trade and environment dynamics to establish goals, programs, procedures, and institutional arrangements toward a more sustainable future (Rockstrom and Klum, 2015; Sachs, 2015).

For every one small and medium sized business harmed by free trade under USMCA, there were five that came out ahead and got insulated from international competition (Canadian Federation of Independent Businesses, 2018). Also, smes owners born in foreign countries are more likely to export despite that they may have less opportunities compared to national - born owners (Orser et al., 2010)_. A small or medium business owner being born outside the country of citizenship might make it more likely to seek international opportunities but it might make it harder to grow a business, a key components of exporting. More education, experience and being born in foreign country are factors that lead to greater export opportunities.

U.S. small and medium business leaders would like to expand USMCA as an objective of an opportunity to grow U.S. exports in both Canada and Mexico, the neighboring and partner countries, but the trade tariffs recently imposed are complicated and are a large burden for the renegotiation.

Small and medium firms are up to the challenge of building relationships with local and foreign business communities to harness the benefits of renegotiated USMCA. The cross-border growth of sMEs is lagging behind, missing business opportunities on their contributions to local marketplaces and economies, mainly for not having full access to infrastructure, credit, knowledge, regulatory expertise and competitive technology 
(Gasiorowski-Denis, 2015). A regional vision on small and medium sized business opportunities could help ramp up infrastructure of all the three partners.

\section{PROPOSALS OF CHANGES AFTER RENEGOTIATING USMCA}

Any change on USMCA should affect small and medium business as different, varied and broad as the nature of business itself. Renegotiations of USMCA have an impact on manufacturing and services SMEs not only determined by industry and location while potentially affecting by benefitting those of one country and harm others from the other countries, such as the case of textile manufacturers and clothing retailers.

A fair-trade deal for sMEs must have reciprocal duty-free access for goods and services and trade balanced to expand competitive market opportunities for the three USMCA partners.

Mexican SMEs have great limitations that restricts integration and position themselves at the lowest levels of the value chain, mainly due to competition of U.S. and Canadian small and medium enterprises. Thus, the technological transfer and economic impact is not the best for the regions where the SMES are settled. Mexican small and medium enterprises explore possibilities to get involved and integrated into international investment, production, logistics and trade flows, as it has been reported by the analysis of Hernández and Carrillo (2018) on aeronautics companies taking advantage of strategic global market location, availability of resources and capabilities, favorable public policy and administration and local integrators.

However, local smes to get insertion and integration into the value chain of the aeronautics sector require to meet several factors
(Hernández, 2015) and to overcome barriers related to a vertical integration (Carrincazeaux and Frigant, 2007) large investment, dynamics of production and quality issues.

In Baja California, some sMEs counting on access to required resources and capabilities entered the aerospace sector. The study of Hernández and Carrillo (2018) found that SMEs holding a certification may have the capacity to supply at different levels of the value chain after overcoming the obstacles of meeting the requirements of production and facing the complexity of management.

USMCA affects employment and jobs in small and medium-sized enterprises that rely on high-volume trade with neighboring partner countries. The death of USMCA may result in potential vanquish of jobs at the small and medium-sized businesses that rely on trade between the country members. In other words, among the benefits, the SMEs create the needed employment. To address employment, jobs and wages challenges posed by technological developments and macroeconomic policies to SMEs, it is not through protectionism but through restraining a robust social safety net through provided by better regulations and strong enforceable labor laws.

SMEs in dynamic industrial sector offer diversification of products and services for potential and real international markets. However, USMCA renegotiated should not include increased levels of protection and strengthen the rules of origin by increasing contents requirements for one partner.

The proposal on the rules of origin should be based on North American content to avoid contentions among the countries.

SMEs need to adapt to whatever the changes of the renegotiation details might be which may involve a disruptive flurry of activities. Changes on USMCA normal as the result of 
negotiations will affect profoundly the business models of sME due to disruptions on reserves and redundancies to protect against interruptions on the value supply chain. Suppliers supporting the activities of SMEs are being destabilized by the ongoing trade renegotiations giving rise to speculations and doubts on trade policy. To emerge from this period of trade and economic destabilization, SMEs need to have and maintain a strong resolve as well as the capacity to nimble respond managing change out of this tumultuous chaotic situation (Galarneau, 2017).

After renegotiations of USMCA, the SMES will need to identify their new consumer markets and to design new business models, new suppliers, logistics and transportation modes of goods, etcetera.

Stakeholders and public-private partnerships could be involved in the formulation of public policies and influence sMes regulations to improve and make easier cross-border trade. Public-private partnership is a model that can serve to SME for knowledge sharing and make information accessible such as the partnerships between MasterCard and IDB Export-Import Bank and the International Trade Commission.

Small and medium-sized businesses are optimistic about the renegotiations of USMCA despite that prospects turn around their upbeat attitude due to escalating disputes between the proposals of partners. SMEs remain as hot commodities to be sold as they should expand their current business while buyers are willing to pay more. Thus, SMEs to be sold are growing and increasing the median revenue in the marketplace.

On the UsmCA renegotiations an issue that is a priority for Mexico is the inclusivity of SMEs. Negotiated UsMCA could encourage greater participation by SMEs in trade and boost the competitiveness. Transparency for SME and macroeconomic knowledge are potential issues to be developed. A core values of the renegotiated USMCA should be transparency and accountability of market regulations to expand opportunities of SMEs for public institutional engagement with a proper governance system arrangement to set up the new agreement.

The UsMCA renegotiation should address the effects of the potential impacts of trade on environment, labor and associated social conflicts such as the proposed environmental reviews of trade agreements (Salzman, 2001). The renegotiated UsMCA could state that each country's environmental laws, regulations and standards must reflect national priorities and preferences to be considered USMCA - consistent unless a challenge can demonstrate the contrary, with convincing evidences-. Therefore, local environmental challenges can remain in all three countries and must be nondiscriminatory. USMCA renegotiation should draw from the experience of the model developed by the European Union.

\section{USMCA RENEGOTIATION SCENARIOS AND PROPOSALS}

Canada and Mexico are already preparing for a post-USMCA scenario, waiting for some conciliatory signal from the other partner in USMCA, United States, after the threat of withdrawing from the agreement, but still in a dialogue. In fact, both countries are launching to seal new business alliances and negotiating with the TPP and with nine other markets. However, if United States withdraws from usmca, Canada and Mexico are willing to maintain it.

Mexican and Canadian small and medium sized business need to prepare to an eventual break up of UsmCA. However, trade ministers of the three partners have stated to be com- 
mitted to "an accelerated and comprehensive negotiation process that will upgrade our agreement and establish 21st century standards to the benefit of our citizens" (Global Affairs Canada, 2017).

One possible scenario for Canadian sMes if USMCA dies, is the resurrection of the Canada-United States Trade Agreement while the scenario for Mexican SMEs is to move to wTO tariffs. In the scenario of ending the USMCA, Canada have the option to apply the bilateral free trade agreement between Canada and United States. Resurrecting the Canadian-United States bilateral free trade agreement is a limited option for sMes of both countries since it still requires action from Canadian Parliament and U.S. Congress. It is hardly to imagine passing on an opportunity for sMEs. Mexico has the option to pursue a bilateral agreement with Canada and United States.

For small or family owned business that not have the resources and capabilities to develop some business strategies to survive and growth under the scenario of the USMCA, it is important for smes to find ways and establish initiatives for strategic alliances and partnerships to complement business efforts in collaboration with other institutional public and private organizations to maximize competitiveness and efficiency.

In a scenario in which USMCA continues as an agreement between Canada and Mexico, SMEs from both countries, exporting or importing could operate under the actual tariffs and rules and the challenge could be the transshipment of products and services between Canada and Mexico through the U.S. territory. In this scenario, United States, could impose non-tariff barriers, longer inspections at the borders, etcetera, just to make trade between Canada and Mexico more complex and difficult. U.S. has mused about imposing $20 \%$ tariff on imports from Mexico aiming to fund construction of a border wall.

SMEs should design scenarios in front of the potential USMCA withdrawal and their differentiated impacts on trading among the parties. The scenario should prepare sMEs for the potential end of USMCA. One of these scenarios, "Just in case Plan" has been designed for the Small Business in Western Canada establish a committee to promote government procurement and identification of opportunities for training, business interested in becoming trading partners, development of data bases, consultations and other activities related.

Granting access to Canadian sub federal procurement, U.S. federal government procurement and Mexican government procurement system is beneficial for sMes suppliers and providers of goods and services. This granted access to government procurement would provide business opportunities for SMES, increasing transparency y reducing institutional corruption.

Entrepreneurs and business managers of SMEs will need to design and implement a long term strategy with short term alternatives to ultimately achieve success in this new world order of trade protectionism (Galarneau, 2017). smEs have to source the best available data and information to design and implement strategic decisions to face uncertainties.

Regarding the USMCA renegotiation issues on agriculture-related objectives should be the proposal to establish new regulations for seasonal and perishable products with the corresponding separate domestic industry provisions in antidumping and countervailing duties proceedings. Decisions on antidumping and countervailing duties can be challenged through a mechanism to re- 
view determinations before an extraordinary challenge committee.

A major issue for USMCA renegotiation is the mechanism of Investor State Dispute Settlement (ISDS) to afford greater protection to domestic and foreign investors. USMCA renegotiation proposes effective and adequate protection of intellectual property rights.

The proposals for UsMCA negotiations include government procurement practices and opportunities for government contracts to U.S. firms, severely restricting opportunities for Mexican and Canadian companies. Currently, usmcA prohibits preferential treatment and gives equal access to the three partners companies. Foreign sMEs firms and domestic sMEs have the same rights, protections and benefits which require national governments to give "fair and equitable treatment", compel fair compensation for expropriated property (Hufbauer, 2016) and challenge discriminatory treatment.

Institutional comprehensive programs and policies are needed to support sMEs to achieve and upgrade potential capacities and develop organizational and technological capabilities, which may be aimed to facilitate access mechanisms that allow them to insert in the integration and internationalization processes of value added chains. Financial and other programs aimed to strengthen the international trade processes of SMEs are necessary to support these companies that provide important benefits to the economies of the country members of USMCA.

Workers would like to have higher wages in the case of Mexico, but government considers that the labor policy is a domestic matter and should be excluded the discussion in renegotiations of USMCA (Quinn and Martin, 2017).

Entrepreneurs and business managers of SMEs will need to design and implement a long term strategy with short term alternatives to ultimately achieve success in this new world order of trade protectionism (Galarneau, 2017).

The renegotiated UsMCA should be more flexible than the original one in many provisions related to SMEs, including on rules of origin that could soon become obsolete. The new UsmCA has the opportunity to fully take into account the potential development of vertiginous technological change.

To make an analysis of the main factors involved in the process of USMCA renegotiation to help the decision and policy makers to meet the challenges posed to SMEs by the recent developments in economic process of globalization, political power, regional market, fair trade, investment, technological changes, etcetera, all the stakeholders must be engaged in the design of policy solutions to the difficult and complex challenges confronting the SMEs in the renegotiated USMCA.

\section{CONCLUSIONS}

USMCA renegotiation is a good opportunity to realize the economic cooperation relationships among the sMEs of partners as a new habit of fair-trade strategic partnership in order to take full advantage of all the economic opportunities it has created. The renegotiated USMCA must facilitate trade by small-andmedium-sized enterprises, considering that these sMEs constitute a majority of exporters in United States and Canada.

USMCA as the North American free market has given SMEs an unprecedented amount of opportunities and choices that have enabled to realize the critical components of trade liberalization. USMCA has been largely beneficial to the three country members and should be renegotiated, modernized to reflect developments and maintained, because it is a 
valuable opportunity SMEs to embolden the gains provided by USMCA. Focus on issues that sidestepping controversy that make a positive difference for SMEs in the renegotiated USMCA could create more jobs of quality and provide the workers more security.

Business leaders, politicians, government officials, business organizations, communities, companies, employees, etcetera, all should be concerned on the processes of USMCA renegotiations to expand opportunities on fair trade and environmentally sustainable development.

Provisions in USMCA renegotiation could be used to modernize it through the deepening of commitments and further cooper- ation of sMes addressing all the challenges. All the options should be on the table for modernizing USMCA through a process of renegotiation, to boost North American competitiveness of sMEs and better address the conditions of international trade, commerce and investment, challenge regulations for liberalizing and reforming the agreement.

Renegotiation of USMCA should further advance trade liberalization of sMEs goods and services instead of protecting national trade interests and avoiding regulations that reduce trading opportunities such as more restrictive rules of origin or public procurement requirements. $\mathbf{G}$

\section{REFERENCES}

Aguilar Alvarez, G., and Park, W.W. (2003). The new face of investment arbitration: NAFTA Chapter 11. Yale Journal of International Law, 28(2), pp. 365-407.

Anderson H., C. (2017). The future of the North American Free Trade Agreement [Scowcroft Paper no. 12]. Scowcroft Institute of International Affairs and Mosbacher Institute for Trade, Economics, and Public Policy, Texas, TX, United States.

Baldwin, J., and Gu, W. (2003). Export-market participation and productivity performance in Canadian manufacturing. Canadian Journal of Economics, 36(3), pp. 634-657.

Bergsten, C.F. (2017). Trade balances and the NAFTA renegotiation [Policy Brief 17-23]. Peterson Institute for International Economics, Washington, DC, United States.

Bolio, E., Remes, J., Lajous, T., Manyika, J., Ramírez, E., and Rossé, M. (2014). A Tale of Two Mexico's: Growth and Prosperity in a Two-Speed Economy [Report]. [online] McKinsey Global Institute, <https://www.mckinsey.com/featured-insights/ americas/a-tale-of-two-mexicos $>$.

Canadian Federation of Independent Businesses (2018). Small businesses concerned about potential changes to NAFTA: Survey. [online] Canadian Federation of Independent Businesses (CFIB), August 16. Available at: <https://www.cfib-fcei.ca/ en/media/small-businesses-concerned-about-potential-changes-nafta-survey> [Retrieved January 09, 2018].

Carpentier, Ch.-L. (2006). NAFTA Commission for Environmental Cooperation: Ongoing assessment of trade liberalization in North America. Impact Assessment and Project Appraisal, 24(4), pp. 259-272. DOI: 10.3152/147154606781765048 
Carrincazeaux, C., and Frigant, V. (2007). The internationalization of the French aerospace industry: To what extent were the 1990s a break with the past? Competition and Change, 11(3), pp. 261-285.

CBC News (2018). Ontario boating industry to feel the sting of retaliatory Canadian tariffs on U.S. watercraft. Boat prices expected to jump 15 per cent after tariffs take effect July 1. CBC News, Jun 25. Available at: <https://www.cbc.ca/news/ canada/sudbury/sudbury-boating-tariffs-1.4718718> [Retrived July 30, 2018].

Condon, B. (2018). From nafta to usmca: Two's company, three's a crowd. Latin American Journal of Trade Policy, 1(2), pp. 30-48. DOI: 10.5354/0719-9368.2019.52140

Corchado, A. (2017). Specter of corruption looms over Mexico as NAFTA talks get rolling. The Dallas Morning News, August 14.

Dubbert, J., and Sengenberger, J. (2018). Preserving and modernizing NAFTA a free trade agreement for a new generation [Policy Paper no. 005, February 28]. Millennial Policy Center, Denver, CO, United States. [online] Available at: <https:// millennialpolicycenter.org/wp-content/uploads/2019/03/180228_MPC_Policy Paper_Preserving_and_Modernizing_NAFTA.pdf $>$.

Export.gov (2017). Mexico - eCommerce. [online] International Trade Administration, Export.gov, <www.export.gov> [Retrieved September 14, 2017].

European Commission (2016). CETA: EU and Canada agree on new approach on investment in trade agreement [Press Release, February 29]. [online] Brussels: European Commission. Available at: <http://europa.eu/rapid/press-release_IP16-399_en.htm> [Retrieved May 18, 2017].

Freund, C. (2017). Streamlining rules of origin in NAFTA [Policy Brief 17-25]. Peterson Institute for International Economics, Washington, DC, United States.

Gaines, S.E. (2007). Environmental policy implications of investor-state arbitration under NAFTA Chapter 11. International Environmental Agreements: Politics, Law, and Economics, 7(2), pp. 171-201.

Galarneau, S. (2017). Canadian small businesses impacted by talk of new NAFTA. Global Trade Magazine, International Trade, February 24. [online] Available at: $<$ https://www.globaltrademag.com/in-the-news/canadian-small-businessesimpacted-talk-new-nafta/>.

García Grande, E., and Echevarría Lasaga, J. (2019). usmCA: una primera aproximación al nuevo NAFTA. Boletín Económico de ICE, 3110, pp. 59-74. DOI: 10.32796/ bice.2019.3110.6782

Gasiorowski-Denis, E. (2015). The big business of small companies. [online] International organization for Standarization, March 4. Available at: <https://www.iso. org/news/2015/03/Ref1937.html>.

Hernández, J. (2015). Las empresas mexicanas en la cadena de valor de la industria aeronáutica. Doctoral Thesis. Facultad Latinoamericana de Ciencias Sociales Sede México, CDMX, Mexico.

Hernández, J., and Carrillo, J. (2018). Possibilities of Mexican smes insertion in the aerospace industry value chain, the Baja California case. Estudios Fronterizos, 19(e002), pp. 1-19. DOI: 10.21670/ref.1802002 
Hufbauer, G.C. (2016). Investor-State dispute settlement. In: C. Cimino-Isaacs and J.J. Schott (eds.), Trans-Pacific Partnership: An assessment. Washington, DC: Peterson Institute for International Economics.

Hufbauer, G.C., and Schott, J.J. (2005). NAFTA Revisited: Achievements and Challenges. Washington, DC: Peterson Institute for International Economics.

Hufbauer, G.C., and Wong, W.F. (2011). Corporate tax reform for a new century [Policy Brief 11-2]. Peterson Institute for International Economics, Washington, DC, United States.

Hufbauer, G.C., Cimino, C., and Moran, T. (2014). NAFTA at 20: Misleading charges and positive achievements [Policy Brief 14-13]. Peterson Institute for International Economics, Washington, DC, United States.

International Trade Administration (2016). Exporter Database. [online] TradeStats Express $^{\text {Tw }},<$ http://tse.export.gov/EDB/SelectReports.aspx $>$ [Retrieved December $16,2016]$.

Kelly, D. (2018). Canadian Federation of Independent Business (CFIB). Canada.

Kondonassis, A.J., and Malliarls, A.G. (1996). NAFTA: Old and new lessons from theory and practice with economic integration. North American Journal of Economics \& Finance, 7(1), pp. 31-41. DOI: 1016/S1062-9408(96)90020-0

Kravis, I.B. (1970). Trade as a handmaiden of growth similarities between the 19th and 20th centuries. Economic Journal, 80(320), pp. 850-872. DOI: 10.2307/2229902

Krueger, A.O. (1992). Government, trade, and economic integration. American Economic Review. Papers and Proceedings of the Hundred and Fourth Annual Meeting of the American Economic Review, 82(2), pp. 109-114.

Lewis, W.A. (1980). The slowing down of the engine of growth. The American Economic Review, 70(4), pp. 555-564.

Lileeva, A., and Trefler, D. (2010). Improved access to foreign markets raises plant-level productivity...for some plants. The Quarterly Journal of Economics, 125(3), pp. 1051-1099. DOI: 10.1162/qjec.2010.125.3.1051

Martineau, C., and Pastoriza, D. (2016). International involvement of established SMEs: A systematic review of antecedents, outcomes and moderators. International Business Review, 25(2), 458-470. DOI: 10.1016/j.ibusrev.2015.07.005

Mayer, T., and Ottaviano, G.I.P. (2008). The happy few: The internationalisation of European firms. News facts based on firm-level evidence. Intereconomics, 43(3), pp. 135-148. DOI: 10.1007/s10272-008-0247-x

Melitz, M.J. (2003). The impact of trade on intra-industry reallocations and aggregate industry productivity. Econometrica, 71(6), pp. 1695-1725.

OECD (2017). Enhancing the contributions of sMEs in a global and digitalized economy. Meeting of the OECD Council at Ministerial Level, Paris, 7-8 June.

Office of the Chief Economist (2016). Majority-female owned exporting SMEs in Canada. The Canadian Trade Commissioner Service, Ottawa, ON, Canada.

Global Affairs Canada (2017). Trilateral statement on the conclusion of NAFTA round one [Press Release August 20]. Global Affairs Canada, Ottawa, ON, Canada. 
Orser, B. (2007). Canadian Women Entrepreneurs, Research and Public Policy: A Review of Literature. [Women and Enterprise Working Paper]. University of Ottawa Telfer School of Management. Ottawa, ON, Canada.

Orser, B., Spence, M., Riding, A., and Carrington, C.A (2010). Gender and export propensity. Entrepreneurship Theory and Practice, 34(5), pp. 933-958. DOI: 10.1111/j.1540-6520.2009.00347.x

Poggesi, S., Mari, M., and De Vita, L. (2016). What's new in female entrepreneurship research? Answers from the literature. International Entrepreneurship and Management Journal, 12(3), pp. 735-764. DOI: 10.1007/s11365-015-0364-5

Quinn, G., and Martin, E. (2017). A NAFTA win for Trump may rest on helping Mexican workers get a raise, Bloomberg, Businessweek, August 7.

Rockstrom, J., and Mattias, K. (2015). Big World, Small Planet: Abundance within Planetary Boundaries. New Haven: Yale University Press.

Sachs, J. (2015). The Age of Sustainable Development. New York: Columbia University Press.

Salzman, J. (2001). Executive Order 13,141 and the Environmental Review of Trade Agreements. American Journal of International Law, 95(2), pp. 366-380. DOI: $10.2307 / 2661402$

Sinclair, S. (2015). NAFTA Chapter 11 Investor-State Disputes. Canadian Centre for Policy Alternatives, Ottawa, ON, Canada.

Torres, B. (2002). The North American agreement on environmental cooperation: Rowing upstream. In: C.L. Deere and D.C. Esty (eds.), Greening the NAFTA: Lessons for Hemispheric Trade. Cambridge: The MIT Press.

U.S. Chamber of Commerce (2015). NAFTA Triumphant: Assessing two decades of gains in trade, growth, and jobs. [online] Chamber of Commerce, October 27. Available at: <https://www.uschamber.com/sites/default/files/documents/files/ nafta_triumphant_updated_2015.pdf>

U.S. Chamber of Commerce (2017). The facts on NAFTA: Assessing two decades of gains in trade, growth, and jobs. [online] U.S. Chamber of Commerce, March 8. Available at: $<$ www.uschamber.com/report/the-facts-nafta-assessing-two-decadesgains-tradegrowth-and-jobs $>$.

Villarreal, M.A., and Fergusson, I.F. (2019). NAFTA renegotiation and the proposed United States-Mexico-Canada Agreement [CRS Report R44981, February 26]. Congressional Research Service, [online] Available at: $<$ https://crsreports.congress. gov/product/pdf/R/R44981>.

Walmsley, T., and Minor, P. (2017). Reversing nAfTA: A supply chain perspective [Working Paper, March]. [online] ImpactECON, Economic and Trade Analysis. Available at: <https://impactecon.com/wp-content/uploads/2017/02/NAFTAFestschrift-Paper-1.pdf $>$.

Wilson, Ch. (2017). Mexico and the NAFTA renegotiations [Webcast]. [online] Wilson Center, August 15. Available at: <https://www.wilsoncenter.org/event/mexicoand-the-nafta-negotiations $>$. 